\title{
The Influence of Corporate Social Responsibility (CSR) Disclosures on Corporate Financial Performance with Industrial Types as Moderating Variables
}

\author{
Ivani Juni Nainggolan \\ Faculty of Economics and Business \\ Universitas Padjadjaran \\ Sofik Handoyo \\ Faculty of Economics and Business \\ Universitas Padjadjaran
}

\begin{abstract}
This study aims to examine the effect of implementing Corporate Social Responsibility (CSR) on the company's financial performance, with the industry type as a moderating variable. CSR disclosure was measured using CSR disclosure under ISO 26000. Return on Asset is a proxy to measure the company's financial performance. The type of industry was divided into a high profile and low-profile company. The research subjects are the leading sector companies (raw material producing industries) and the second sector (manufacturing industries) which consist of various sectors namely agriculture, mining, basic and chemical industries, various industries, and consumer goods which are listed on the Indonesia Stock Exchange in 2012-2013. Partially, the results showed that the disclosure of CSR implementation and industry type positively and significantly affected the company's financial performance, and the type of industry succeeded in becoming a moderating variable that influenced the relationship between CSR disclosure and the company's financial performance. Simultaneously, the results of the study also show that there is a significant effect of the level of disclosure of Corporate Social Responsibility (CSR) on financial performance with industry type as a moderating variable.
\end{abstract}

Keywords: Corporate Social Responsibility; Disclosure, ISO 26000, Return on Asset, Industry Type

\section{Introduction}

Financial performance is an indicator of the company's success in winning competition in the business world. Good financial performance is characterized by increasing profits, increased sales of products in the market, or high stock values. However, besides financial performance, there are other things that are not less important, namely sustainability. The primary key to achieving sustainability is the public acceptance of the company's presence. A sustainable business is an organization that ensures that all of its activities and production processes take into consideration the impact on the environment. In other words, economic decision making based solely on financial performance is considered less relevant at this time. Another important thing to be considered by a business organization is how its social and environmental performance. 
The idea of paying attention to social and environmental performance is reflected in the triple bottom lines. The Triple Bottom Line is a concept of measuring corporate performance holistically by including not only a measure of economic performance in the form of profit but also a measure of social awareness and environmental preservation. The popular term that represents the Triple Bottom Line we often shortly called with 3P (People-Planet-Profit). One of the bestknown forms of social and environmental responsibility is Corporate Social Responsibility (CSR). The World Business Council of Sustainable Development (WBSCSD) describes CSR as a business commitment to contribute to sustainable economic development, working with employees, their families, local communities and the wider community to improve the quality of life together.

In Indonesia, the discourse on awareness of the need to protect the environment and social responsibility has been regulated in the Limited Liability Company Law No 40 article 74 of 2007 and also Article 66 paragraph 2c of Law No. 40 of 2007, which requires all companies to report on the implementation of social and environmental responsibilities in the annual report. However, the regulation issued by the government does not guarantee the implementation of social and environmental responsibilities of all companies in Indonesia in good condition. It can be seen from the fact that there are still many cases which are caused by companies not paying attention to social and environmental conditions in carrying out their business operations.

One of the cases related to the failure of the company to work on its social and environmental responsibilities can be seen in the case of environmental pollution in Buyat Bay by PT. Newmont Minahasa Raya which has claimed several human victims, and damaged the ecosystem. There is another case of Nike Inc which has sacrificed a number of workers around the world, especially in Indonesia who work for companies by violating some union rules such as wages received by workers under decent living standards even though they work above normal working hours, employing many underage children for increasing production capacity at low prices, not rewarding overtime work and others.

Another problem that is also quite concerning in many companies in Indonesia is the management's low attention to employee problems, primarily work safety. The number of occupational accidents in Indonesia ranks highest among ASEAN countries in 2005. According to the International Labor Organization (ILO) data, in Indonesia, there are 99,000 cases of workplace accidents on average per year. Of that total, around 70 percent are fatal, namely death and disability for life (Jakarta Pos Sore, April 24, 2014). The high number of work accidents in Indonesia reflects that there are still many companies in Indonesia that have not implemented their social responsibility properly.

Until now, in Indonesia, there are no standards that directly regulate the implementation of CSR. However, the manifestation of the company's concern for social and environmental responsibility can now be answered with ISO 26000 certification which is a new international standard that can be used as a guideline for companies in the public sector or private bodies in developing and developed countries in carrying out their social and environmental responsibilities. The implementation of social and environmental responsibilities that are often stated through CSR programs is still relatively low in Indonesia compared to other Asian countries. This shows that there are still many companies in Indonesia that have not realized the importance of paying attention to their social and environmental responsibilities. 
The implementation of social and environmental responsibilities of a company is influenced by various factors, one of which is related to its financial performance. It cannot be denied that the source of funding for a company's CSR program must be related to the financial condition of the company itself. The company's financial performance can be seen from the company's ability to generate profits, sales levels, the value of the company's shares, and others. The good or bad financial performance of a company will influence the investor's decision on the investment made. Good financial performance will encourage investors to invest their capital as well as vice versa. Good financial performance will also encourage the company's management to disclose its CSR even better because financial performance alone is not enough to attract investors. The company's financial performance must also be balanced with the acceptance and recognition of other stakeholders that can be identified from social and environmental responsibility.

Slack resource theory suggests that better financial performance potentially results in the availability of slack (financial or others) resources that provide opportunities for companies to invest in social performance domains. The theory explains that better financial performance can be the right tool to predict better social performance. With various considerations and the theory indicates that there is a positive relationship between financial performance and disclosure of environmental, social responsibility. In addition to the company's financial performance factors, there are other things that are not less interesting to note that are factors in the implementation of CSR programs, namely the type or type of industry of a company. Some international studies, such as those conducted by Waddock and Graves (1997) and Elsayed and Paton (2007) have used industrial types as a determinant of the good and poor environmental performance of a company. It is reasonable because environmental commitments can be quite crucial for specific industries (Scott, 2005 in Elsayed and Paton, 2007).

Studies of related themes such as CSR have been presented in the academic literature for approximately 45 years. However, until now, the results of the existing research are still controversial and show different results and even contradictions between the results of research with one another. Fauzi Hasan's research (2009) shows that there is a positive relationship between CSR and financial performance under the theory of slack resource theory. The research of $\mathrm{Ni}$ Luh Kade and I Gusti Ngurah Agung (2013) also shows that CSR disclosure has a positive and significant effect on financial performance. It means that the higher the CSR disclosure, the higher the company's financial performance.

\section{Literature Review and Hypotheses}

\section{Stakeholder Theory}

The basis of stakeholder theory states that the success of a company depends not only on the success of management in building relationships with shareholders but also by management's ability to build relationships with other stakeholders. According to The Clarkson Center for Business Ethics (1999) in Magness (2008) stakeholders can be grouped into two categories, namely: Primary stakeholders (parties that have an economic interest in the company and bear risks, for example, investors, creditors, employees, government, local community) and Secondary stakeholders (stakeholders who have the capacity to mobilize public opinion). The relationship between the company and stakeholders influences each other but the economic viability of the company's life is not determined by this type of stakeholder. 
Stakeholder theory states that a company is not an entity that only operates for its interests but must also provide benefits to stakeholders. Gray, et al. (1994 in Ghozali and Chariri, 2007) state that the survival of a company depends on stakeholder support and that support must be sought so that the company's activities are to seek that support. The more powerful stakeholders are, the higher the company's efforts to adapt. Social disclosure is considered as part of the dialogue between the company and its stakeholders. "

Ulman (1985), in his research, revealed that corporate social performance is a form of stakeholder theory implementation. Ulman (1985) in Indriana (2009) explains that changes like the business environment encourage companies to know the responsibility for their broader constituents not only to shareholders. Stakeholder theory also helps companies solve social problems. CSR is meant is not only limited to the involvement of companies in the community but more broadly, namely to the workforce, making products safer, pollution, and other things related to the environment. Disclosed by Ulman (1985) in Indriana (2009) that companies that are concerned with their stakeholders and environmental issues will be more motivated to perform and express their performance well.

\section{Corporate Social Responsibility and Financial Performance}

According to ISO 26000, Corporate Social Responsibility is an organization's responsibility for the impacts of its decisions and activities on society and the environment that are manifested in the form of transparent and ethical behavior that is in line with sustainable development and community welfare, consider stakeholder expectations, in line with established laws and international behavioral norms, and integrated with the organization as a whole. CSR is one of the ways in which the company expresses its values and behavior in the hope that it can meet the needs of all stakeholders, not only customers or investors but also suppliers, employees, government, local communities, and society as a whole. With the existence of CSR, the company will be required to pay attention to economic, social, and environmental issues in a balanced manner. CSR is not just talking about how to meet the needs of stakeholders but also will bring a competitive advantage for the company.

One standard that can be used by companies in carrying out CSR activities is ISO 26000, the guidance standard on social responsibility. ISO 26000 was published by ISO (International Standards Organization) in early November 2010 after $93 \%$ of ISO member countries including Indonesia were approved in it. ISO 26000 guideline consists of 6 chapters and contains seven principles, two basic practices, seven core subjects, 41 issues, and six practices for integrating organizational social responsibility. ISO 26000 is an ISO response to the increasing worldwide attention to the issue of corporate social responsibility (corporate social responsibility, CSR). Chapter six ISO 26000 explains the core subjects and issues related to social responsibility. Each subject contains information about the scope, relation to social responsibility, related principles and considerations, and activities and expectations for the subject.

According to IAI (2007), financial performance is the company's ability to manage and control the resources it has. It can be concluded that financial performance is an activity carried out by the company in measuring the success of the company in generating profits so that it can see the prospects, growth, and potential for good development of the company by relying on existing resources. Higher financial performance causes an increase in stakeholder prosperity. In addition, based on slack resource theory (Waddock and Graves, 1997 in Dean, 1998 cited from 
Fauzi et al., 2009), improving financial performance makes companies have more opportunities to improve social performance in all aspects. Based on the explanation mentioned above, the hypothesis can be formulated as follows:

Hypothesis 1: Disclosure of Corporate Social Responsibility (CSR) affects the company's financial performance.

\section{Industrial types and Financial Performance}

According to Utomo (2000), one of the interesting things to note when testing the level of corporate social disclosure is the difference in company characteristics. One of the differences in these characteristics is the industrial type, namely a high profile and low profile industry. Companies that are included in the type of high profile industry are companies that have a high level of sensitivity to the environment, a high level of political risk, or a strong level of competence (Robert, 1992 in Utomo, 2000). Besides, companies that are included in the high profile category are generally companies that get much attention from the public because the company's operating activities have the potential and possibility of dealing with the interests of the wider community. The high profile industry is believed to do more social responsibility disclosure than the low profile industry. It is due to high profile companies having company operations that modify the environment a lot and involve complex stakeholders.

Companies with high profile industry types are generally very vulnerable to public attention. Thus high profile companies, need to accommodate the interests and willingness of groups of stakeholders in the form of company policy (Shrivastafa, 1995 in Dirgantari Novi). The classification of industrial types by many researchers is very varied. Diekers and Perston (1977) in Hackston and Milne (1996) argue that extractive industries are high profile industries whereas Robert (1992) in Hackston and Milne (1996) classified automotive, aviation and oil companies as high profile industries. Pattern (1991) in Hackston and Milne (1996) group mining, chemical, and forestry industries as high profile industries.

In this study the company will be grouped into high profile and low profile industries according to Muhammad Rizal Hasibuan (2001) in Utomo (2000), which includes oil and mining, chemical, forest, paper, automotive, aviation, agribusiness, tobacco and cigarettes, food and beverages as a high profile company while buildings, textiles and textile products, personal products, and household products are low profile companies. Based on the explanation mentioned above, the hypothesis can be formulated as follows:

Hypothesis 2: Industrial type strengthens the relationship of disclosure of Corporate Social Responsibility (CSR) with the company's financial performance.

\section{Methodology}

This research was conducted on companies from various industrial sectors listed on the Indonesia Stock Exchange (IDX). The research used secondary data form Annual Report for the period 2012-2013 obtained from www.idx.co.id. The sample selection used a purposive sampling method, with the criteria that the company discloses information on social responsibility in 2012 and has complete data related to the variables used, namely the 2013 ROA and companies included in the leading sector (raw material producing sector) and the other sector (manufacturing industry ). From this sample criteria, a sample of 63 companies was obtained. The disclosure indicators of Corporate Social Responsibility (CSR) by ISO 26000, published in 2010 are as follows: 


\begin{tabular}{|c|c|}
\hline Category & Disclosure Items \\
\hline $\begin{array}{l}\text { Governance } \\
\text { (5 items) }\end{array}$ & $\begin{array}{l}\text { - } \\
\text { - Tccountability } \\
\text { - Ethical behavior } \\
\text { - Respect for stakeholders' interests } \\
\text { - Respect for the rule of law }\end{array}$ \\
\hline $\begin{array}{l}\text { Human Rights } \\
\text { (7 Items) }\end{array}$ & $\begin{array}{l}\text { - } \text { Due Diligence } \\
\text { - Conditions that pose human rights risks } \\
\text { - Customer Avoidance } \\
\text { - Complaint Resolution } \\
\text { - Discrimination and vulnerable groups } \\
\text { - Civil and Political Rights } \\
\text { - Economic, social and political rights }\end{array}$ \\
\hline $\begin{array}{ll}\text { Labor } & \text { Fundamental } \\
\text { Rights } & \\
\text { (5 Items) } & \end{array}$ & $\begin{array}{l}\text { - Employment and employment relations } \\
\text { - Working Conditions and Social Security } \\
\text { - Employment Dialogue } \\
\text { - Occupational health and safety } \\
\text { - Development of human resources and training }\end{array}$ \\
\hline $\begin{array}{l}\text { Environment } \\
\text { (4 items) }\end{array}$ & $\begin{array}{l}\text { - } \text { Pollution prevention } \\
\text { - Use of sustainable resources } \\
\text { - Mitigation and adaptation to climate change } \\
\text { - Environmental and biodiversity protection and habitat } \\
\text { restoration }\end{array}$ \\
\hline $\begin{array}{l}\text { Fair Operation Practices } \\
\text { (5 items) }\end{array}$ & $\begin{array}{l}\text { - Anti-corruption } \\
\text { - Engagement that is responsible for political affairs } \\
\text { - } \text { Fair competition } \\
\text { - Promotion of social responsibility in the sphere of influence } \\
\text { - Respect for copyright }\end{array}$ \\
\hline $\begin{array}{l}\text { Consumer issues } \\
\text { ( } 7 \text { items) }\end{array}$ & $\begin{array}{l}\text { - Fair marketing with fractual and unbiased information, and } \\
\text { - } \text { Mair contractual practices } \\
\text { - Sustainable consumption } \\
\text { - Services and support for consumers and resolution of } \\
\text { objections } \\
\text { - Protection and privacy of consumer data } \\
\text { - } \text { Access to essential services } \\
\text { - Education and awareness }\end{array}$ \\
\hline $\begin{array}{l}\text { Community } \\
\text { maintenance } \\
\text { development } \\
(7 \text { items })\end{array}$ & $\begin{array}{l}\text { - } \text { Community maintenance } \\
\text { - Maintenance and culture } \\
\text { - Job creation and skills improvement } \\
\text { - Development and access to technology } \\
\text { - Well-being and increase in income } \\
\text { - Health } \\
\text { - Social Investment }\end{array}$ \\
\hline
\end{tabular}

Based on the number of measurement indicators, CSR disclosure can be measured using the following formula: $\frac{\varepsilon \mathrm{Xn}}{41} \times 100$, Where, $\varepsilon \mathrm{Xn}$ is the number of sample company disclosures, and 41 is the number of disclosure items. In 
this study, financial performance was measured using financial ratios, namely ROA. The formula to calculate the ROA = (net income/total asset) $\mathrm{x} 100 \%$. Dummy variables were used to classify industrial types into high profiles and low profiles. Value 2 for high profile companies and 1 low profile company. The equation model was used to test the hypothesis is as follows:

$\mathrm{Y}=\alpha+\beta 1 \mathrm{CSR}+\mathrm{ui}$

$\mathrm{H} 2$ : Tested using multiple linear regression models

$\mathrm{Y}=\alpha+\beta 1 \mathrm{CSR}+\beta 2 \mathrm{~T} 2+\beta 3 \mathrm{CSR} * \mathrm{TI}+\mathrm{ui}$ Where :

Y: Financial Performance

$\alpha$ : Constants

$\beta 1-\beta 3$ : Regression Coefficient

CSR: Disclosure of Corporate Social

Responsibility (CSR)

TI: Industrial Type

ui: Residual, namely the level of error of

the estimator in the study

Meanwhile, to test the regression with moderating variables, the interaction test is used or often called the Moderated Regression Analysis (MRA). Moderated Regression Analysis is a particular application of multiple linear regression where the regression equation contains an element of interaction (multiplying two or more independent variables). In this study, the multiplication variable between CSR disclosure (X1) and industrial type (X2) on the relationship of CSR disclosure (X1) and ROA (Y).

\section{Results}

The results of testing classic assumptions indicate that data is normally distributed. The results of the study also confirm the absence of multicollinearity and heteroscedasticity. The autocorrelation test results prove that there is no autocorrelation in the research regression model. The result of R-Square $\left(\mathrm{R}^{2}\right)$ is 0.145 .
It means that $14.5 \%$ changes in ROA can be explained (influenced) by changes in CSR disclosures moderated by industry types, while $85.5 \%$ are influenced by other unobserved variables.

The simultaneous test results show that the calculated value for the regression model is 3.335, with a significance level (pvalue $)=0.025$. The F-table value for $\alpha=$ 0.05 and free degrees $=3$ and 59 obtained F-table $=2.76$. The value of F-count is greater than F-table (3.335> 2.76), and the significance value is smaller than the error rate of $5 \%(0.025<0.05)$. Thus it can be concluded that with a $95 \%$ confidence level there is a significant effect of the level of disclosure of Corporate Social Responsibility (CSR) on financial performance with industry type as a moderating variable.

The partial test results for the level of disclosure of Corporate Social Responsibility t-count is higher than the value of t-table $(2,814>2,001)$. Moreover, if seen from the significance value of 0.007 , it is smaller than the error rate of 5\% $(0.007$ $<0.05)$. Thus there is a significant effect of the level of disclosure of Corporate Social Responsibility (CSR) on financial performance. Testing $t$ in the industrial type showed that the value of $t$-count is higher than the value of t table $(2,071>2,001)$ and the significance value 0.043 is smaller than the error rate of $5 \%(0.043<0.05)$. Thus it can be concluded that at the $95 \%$ confidence level, there is a significant effect of the type of industry on financial performance.

Partial testing on the interaction variable of disclosure of CSR and industry type obtained the Significance as much as 0.019 , which is smaller than 0.05 . It means that the type of industry moderates the effect of disclosure of Corporate Social Responsibility (CSR) on a financial performance that is proxied by ROA. In other words, the type of industry functions as a moderating variable in the effect of 
disclosure of Corporate Social Responsibility (CSR) on financial performance.

Based on the data analysis that was assisted by using SPSS 16.0 version, it was found that there was a significant effect between the level of disclosure of Corporate Social Responsibility (CSR) on financial performance which was proxied by ROA with industry type as a moderating variable. The results of this study indicate that the type of industry as a moderating variable can strengthen the relationship between CSR disclosure and financial performance. In other words, companies that in high profile category will have a better level of disclosure of Corporate Social Responsibility (CSR) and be followed by improved financial performance.

\section{Conclusion and Suggestion}

Based on simultaneous hypothesis testing that there is a significant effect of the level of disclosure of Corporate Social Responsibility (CSR) on financial performance with industry types as moderating variables. At a 5\% significance level, partial hypothesis testing results that there is a significant effect of the level of disclosure of Corporate Social Responsibility (CSR) on financial performance in companies that in the category of the leading sector (raw material producing industries) and manufacturing industries.

At the 5\% significance level, partial hypothesis testing results that there is a significant effect of the type of industry on financial performance. At the 5\% significance level partial hypothesis testing results that the industry type moderates the effect of disclosure of Corporate Social Responsibility (CSR) based on financial performance which is proxied by ROA or in other words the type of industry functions as a moderating variable in the effect of
Corporate disclosure Social Responsibility (CSR) on financial performance.

Suggestion for future research is to add more samples in order to obtain representativeness of the population. Furthermore, conducting research on the last sector, namely the third sector (service industry) is necessary in order to get an understanding of the nature impact service industry on CSR disclosure. In order to obtain conclusive results, future research is suggested using different instruments of Corporate Social Responsibility (CSR) disclosure and a different financial performance indicator such as level of sales, stock prices, or other financial ratios (ROE, NPM, etc.). The assessment of disclosure of Corporate Social Responsibility (CSR) using an index issued by GRI or another CSR assessment index is suggested to enrich the horizon of methodology research. Lastly, researching for periods of more than one year is suggested to obtain a comprehensive understanding

\section{Refferences}

Aprilia, Astira. 2011. Pengaruh Tingkat Pengungkapan Tanggung Jawab Sosial Perusahaan terhadap Market Value Added dengan Profitabilitas sebagai Variabel Moderating, Skripsi, Fakultas Ekonomi dan Bisnis, Universitas Padjadjaran.

Berete, Moussa. 2011. Relationships between Corporate Social Responsibility and Financial Performance in the Pharmaceutical Industry, Copyright 2011 by Proquest LLC.

Dipraja, Ibnu. 2014. Pengaruh Corporate Social Responsibility terhadap Kinerja Keuangan. Dian Nuswantara University Journal of Accounting Tahun 2014 Hal 1-17. 
Dirgantari, Novi. 2002. Analisis terhadap Perbedaan Ekstensifikasi Praktek Social Disclosure pada PerusahaanPerusahaan Emiten di Bursa Efek Jakarta Berdasarkan Tipe Industri dan Ukuran Perusahaan, Tesis, Fakultas Ekonomika dan Bisnis, Universitas Diponegoro.

Elkington, John. 1998. Canibals With Forks: The Triple Bottom Line in 21stCentury Business, Gabriola Island, BC: New Society Publishers.

Fauzi, Hasan. 2007. The Link between Corporate Social Performance and Financial Performance: Evidence from Indonesian Companies. Issues in Social and Environmental Accounting Vol. 1, No. 1 June 2007 (Pp. 149-159).

Fauzi, Hasan. 2009. The Relationship of Corporate Social Responsibility and Financial Performance: New Evidence from Indonesia Companies (with Idris, Kamil Md). Issues in Social and Environmental Accounting (vol. 3 No. 1).

Gitman, Lawrence J dan Chad J. Zutter. 2012. Principles of Managerial Finance. ... Buku 1. Jakarta: Salemba Empat.

Griffin, J.J., J.F. Mahon. 1997. The Corporate Social Performance and Corporate Financial Performance Debate: Twenty-five years of Incomparable Research. Business and Society 36(1): 5-31.

Hernan, Robert. 2010. This Borrowed Earth : Lessons from the Fifteen Worst Environmental Disasters Around the World. ST Martin's Publisher.

Hirigoyen and Thierry Poulain. 2012. Relationships between Corporate Social Responsibility and Financial Performance: What is the Causality?, Electronic copy available at: http://ssrn.com/abstract=2531631

Jalal. 2013. Pembangunan Berkelanjutan, Tanggung Jawab Sosial Perusahaan (CSR), dan Penanganan Kemiskinan. Diskusi Publik "Akuntabilitas Sosial CSR Industri Ekstraktif dan Peranannya Dalam Penanggulangan Kemiskinan", Jakarta, 18 Juli 2013.

Kiernan, Mattew. 2008. Investing in a Sustainable World: Why Green is the New Color of Money on Wall Street. The Book Publishing Division of American Management Association.

Kieso, Donald E. Ph.D., C.P.A et al.2009. Intermediate Accounting. IFRS Edition. John Wiley and Sons, IncMarciano, Lovasta Holy. 2011. Pengaruh Pengungkapan Corporate Social Responsibility terhadap Price Earning Ratio dan ROA dengan Kepemilikan Saham Asing sebagai Variabel Moderasi, Skripsi, Fakultas Ekonomi dan Bisnis, Universitas Padjadjaran.

Nurani, Maria. 2014. Update on CSR Status \& Trend in Indonesia. Making CSR an Integrated Part of Your Business Workshop - Jakarta, 22 January 2014.

Paskert, James M. 2009. The Impact of Corporate Social Responsibility Practices on Corporate Financial Performances and Consumer Loyalty, Copyright 2009 by Proquest LLC.

P.L Baird, P.C Geylani, dan J.A Robert. 2010. Corporate Social and Financial Performance Reexamined: Industry Effects in a Linier Mixed Model Analysis. J Bus Ethics (2012) 109:367-388 DOI $10.1007 / \mathrm{s} 10551-011-1135-\mathrm{Z}$ 
Purwanto, Agus. 2011. Pengaruh Tipe Industri, Ukuran Perusahaan, Profitabilitas terhadap Corporate Social Responsibility. Jurnal Akuntansi \& Auditing Volume 8/No. 1/November 2011: 1-94.

Romauli, Rifeald. 2012. Implementasi ISO 26000 dan Pelaporan serta Pengungkapan Berdasarkan Standar Global Reporting Initiative, Tesis, Fakultas Ekonomi dan Bisnis, Universitas Indonesia.

Rosiliani, Kadek, dkk. 2014. Pengaruh Corporate Social Responsibility terhadap Kinerja Keuangan Perusahaan. E-Jurnal S1 Ak Universitas Pendidikan Ganesha Jurusan Akuntansi Program S1 Volume 2/No. 1/ 2014.

Saputro, Temmy. 2013. Pengaruh Profitabilitas, Umur Perusahaan, Tipe Perusahaan dan Kepemilikan Manajerial terhadap Kinerja Sosial Perusahaan berdasar ISO 26000, Skripsi, Fakultas Ekonomika dan Bisnis, Universitas Diponegoro.

Sari, Ni Luh Kade dan Suaryana. 2013. Pengaruh Pengungkapan CSR terhadap Kinerja Keuangan dengan Kepemilikan Asing sebagai Variabel Moderator. E-Jurnal Akuntansi Universitas Udayana 3.2 (2013) : 248-25

Sudjana. 2010. Statistika Untuk Ekonomi dan Niaga. Bandung : Tarsito.

Sugiyono. 2008. Metode Penelitian Bisnis. Bandung: CV Alfabeta

Sugiyono. 2009. Statistika untuk Penelitian. Bandung : Alfabeta.

Sunjoyo, Rony, Verani, dkk. 2009. Aplikasi SPSS untuk Smart Riset. Bandung : Alfabeta.

Whalen, Robin. 2013. Corporate Social Responsibility and Its Relationship with Financial Performance, Published by Proquest LLC (2013).

http://darikelas.blogspot.com/

www.csrindonesia.com

$\underline{\text { WwW.idx.co.id }}$

www.sahamok.com 